\title{
Wild Plant Assessment for Heavy Metal Phytoremediation Potential along the Mafic and Ultramafic Terrain in Northern Pakistan
}

\author{
Said Muhammad, ${ }^{1,2}$ Mohammad Tahir Shah, ${ }^{2}$ Sardar Khan, ${ }^{3}$ Umar Saddique, ${ }^{4}$ Nida Gul, \\ Muhammad Usman Khan, ${ }^{5}$ Riffat Naseem Malik, ${ }^{5}$ Muhammad Farooq, ${ }^{1}$ and Alia Naz ${ }^{6}$ \\ ${ }^{1}$ Department of Earth Sciences, COMSATS Institute of Information Technology (CIIT), Abbottabad 22060, Pakistan \\ ${ }^{2}$ National Center of Excellence in Geology, University of Peshawar, Peshawar 25120, Pakistan \\ ${ }^{3}$ Department of Environmental Sciences, University of Peshawar, Peshawar 25120, Pakistan \\ ${ }^{4}$ Department of Chemistry, Abdul Wali Khan University, Mardan 23200, Pakistan \\ ${ }^{5}$ Environmental Biology and Ecotoxicology Laboratory, Department of Environmental Sciences, Faculty of Biological Sciences, \\ Quaid-i-Azam University, Islamabad 45320, Pakistan \\ ${ }^{6}$ Department of Environmental Sciences, Abdul Wali Khan University, Mardan 23200, Pakistan
}

Correspondence should be addressed to Said Muhammad; saidmuhammad1@gmail.com

Received 16 April 2013; Accepted 17 July 2013

Academic Editor: George Perry

Copyright ( 2013 Said Muhammad et al. This is an open access article distributed under the Creative Commons Attribution License, which permits unrestricted use, distribution, and reproduction in any medium, provided the original work is properly cited.

\begin{abstract}
This study investigates the wild plant species for their phytoremediation potential of macro and trace metals (MTM). For this purpose, soil and wild plant species samples were collected along mafic and ultramafic terrain in the Jijal, Dubair, and Alpuri areas of Kohistan region, northern Pakistan. These samples were analyzed for the concentrations of MTM (Na, K, Ca, Mg, Fe, $\mathrm{Mn}, \mathrm{Pb}, \mathrm{Zn}, \mathrm{Cd}, \mathrm{Cu}, \mathrm{Cr}, \mathrm{Ni}$, and $\mathrm{Co}$ ) using atomic absorption spectrometer (AAS-PEA-700). Soil showed significant $(P<.001)$ contamination level, while plants had greater variability in metal uptake from the contaminated sites. Plant species such as Selaginella jacquemontii, Rumex hastatus, and Plectranthus rugosus showed multifold enrichment factor (EF) of $\mathrm{Fe}, \mathrm{Mn}, \mathrm{Cr}, \mathrm{Ni}$, and Co as compared to background area. Results revealed that these wild plant species have the ability to uptake and accumulate higher metals concentration. Therefore, these plant species may be used for phytoremediation of metals contaminated soil. However, higher MTM concentrations in the wild plant species could cause environmental hazards in the study area, as selected metals (Fe, $\mathrm{Mn}, \mathrm{Cr}, \mathrm{Ni}, \mathrm{Co}$, and $\mathrm{Pb}$ ) have toxicological concerns.
\end{abstract}

\section{Introduction}

Owing to toxicity, persistent and bioaccumulative nature, the macro and trace metals (MTMs) contamination represent, one of the most burning threats to soil, plants, human health, and environment [1-5]. Among the MTM, $\mathrm{Na}, \mathrm{K}, \mathrm{Ca}, \mathrm{Mg}, \mathrm{Fe}$, $\mathrm{Co}, \mathrm{Cu}$, and $\mathrm{Zn}$ are essential metals for human health and environment. However, these metals may produce toxicity at their higher concentrations. Whereas, others trace metals (TM) including $\mathrm{Pb}, \mathrm{Cd}, \mathrm{Cr}, \mathrm{Ni}$, and As are extremely toxic even at very low concentrations for living organisms and environment $[3,6]$. These contaminants may have natural (ore deposits or weathering of parent rocks) and anthropogenic (mining, minerals processing, and fly ash) sources [2, 7-9]. Although, in most cases, soil enrichment with MTM is due to the hazardous waste pollution, there are many cases where soil derived from mineralized rocks is naturally enriched with these metals $[2,7]$.

Generally, the mafic and ultramafic terrain are enriched with MTM including $\mathrm{Cr}, \mathrm{Ni}, \mathrm{Mg}, \mathrm{Cu}, \mathrm{Pb}, \mathrm{Zn}$ and $\mathrm{Cd}$; and similarly, the weathered soil of ultramafic terrain (serpentine soil) are also enriched with these metals [1,7]. Mining and waste dumping further accelerated the MTM accumulations in soil ecosystem $[2,10,11]$. pH, electrical conductivity (EC), 
and soil organic matter (SOM) are main factors that generally affect the chemistry of these metals in soil and their plant uptake, which may cause environmental problems in the area $[1,2]$.

Accumulations of MTM in soil ecosystem, food safety, and potential health risks are of great concern. Food chain contamination is one of the most important pathways for entry of these metals into the human, animals and other living organism $[7,12]$. Therefore, various techniques have been used to address MTM-contaminated soil. However, phytoremediation has received considerable attention due to being a best and cost-effective technique for metal contaminated soil reclamations $[1,2,7,9,13]$. Researchers have given more attention to these kinds of soil for better understanding of metal nature, toxicity, sources, and plant accumulations [1-13]. However, MTM needs more information to identify the soil contaminations and wild hyperaccumulator plant species along the mafic and ultramafic terrain. Therefore, this study was aimed to elucidate the contamination level via metal enrichment factor (EF), pollution load index (PLI), and bioaccumulation factor (BF). Furthermore, selected wild plant species were evaluated for the phytoremediation ability.

\section{Materials and Methods}

2.1. Study Area. The study area is located in the Kohistan region of northern Pakistan between latitude $34^{\circ} 50^{\prime}$ to $35^{\circ} 06^{\prime} \mathrm{N}$ and longitude $72^{\circ} 43^{\prime}$ to $73^{\circ} 02^{\prime} \mathrm{E}$. It covers approximately a total area of $1800 \mathrm{~km}^{2}$ with $<0.91$ Million populations. Indus River and its tributaries (Dubair and Khan Khwars) are the main sources of agriculture irrigation. This region is warm in summer $\left(32.5^{\circ} \mathrm{C}\right)$, except in high altitude areas, and very cold in winter $\left(-2.4^{\circ} \mathrm{C}\right)$ receiving an annual precipitation of $650 \mathrm{~mm}$ [14].

Geologically, the area is unique as it is composed of the rocks of three different tectonic settings such as the Kohistan island arc (KIA), the Indus suture zone (ISZ), and the Indian plate (IP) (Figure 1). The ISZ is considered as the contact zone between the KIA in the north and the IP in the south. In the study area, the rocks of these different lithologies vary in composition from mafic and ultramafic igneous rocks belonging to KIA and ISZ to metasedimentary rocks of IP [15]. This region has various types of metallic and nonmetallic mineral deposits. According to Miller et al. [16], the huge deposits of chromite are present within the ultramafic rocks (dunite and peridotite) of the ISZ and the KIA at Jijal, Dubair, and Alpuri areas. Presently, the mining of these chromite deposits is carried out on small scale by the local miners.

2.2. Plant Sampling and Analyses. In the study area, wild plant species were randomly collected, properly labeled, and packed in polyethylene bags. Plant species were identified and taxonomically classified with the help of taxonomist in Botany Department, University of Peshawar, Pakistan. For reference, plants grown on the metasedimentary rocks of IP were also collected about $10 \mathrm{~km}$ away from the mafic and ultramafic terrain. All plants were washed and cleaned with tape water, oven dried at $70^{\circ} \mathrm{C}$, and ground into powder with electric grinder. Plant samples of $2.0 \mathrm{~g}$ were taken in Pyrex beaker and digested with a mixture of acids $\left(\mathrm{HNO}_{3}+\mathrm{HClO}_{4}\right.$ and aqua regia), according to the method adopted from Ryan et al. [17]. Plant extract was diluted to $50 \mathrm{~mL}$ with double distilled water (DDW).

2.3. Soil Sampling and Analyses. Surface soil samples of about $1 \mathrm{Kg}$, collected from the base of each uprooted plant sample, were properly labeled and packed in polyethylene bags. For reference, soil was also collected from the base of uprooted reference plant species collected from IP. Samples were air dried at ambient temperature for $72 \mathrm{~h}$, homogenized, and sieved through $2 \mathrm{~mm}$ mesh for further analyses. Soil < $2 \mathrm{~mm}$ fraction was used for physical analyses like $\mathrm{pH}, \mathrm{EC}$, and SOM. Next, soil was ground into powder in ball mill to a finer than $75 \mu \mathrm{m}$ sieve size for MTM determination. Physical parameters ( $\mathrm{pH}$ and EC) were measured according to procedure adopted from Das and Maiti [18], while SOM adopted from Konen et al. [19]. Accurately weighed $0.5 \mathrm{~g}$ oven dried soil was digested in Teflon beaker with a mixture of acids $(\mathrm{HF}+\mathrm{HCl})$ at $130-140^{\circ} \mathrm{C}$ for complete digestion. When acids were completely evaporated, diluted $\mathrm{HCl}$ was added, and the solution volume was made with DDW [11].

2.4. Data Precision and Accuracy. Digested plant and soil samples were analyzed for MTM using atomic absorption spectrometer (Perkin Elmer, AAS-PEA-700). For data precision and accuracy, blanks and standard reference soil and plant materials were included in digestion and subsequent analyses. Each sample was digested and analyzed in triplicate, and mean values were taken for further interpretation. Reproducibility of the triplicate samples was found within 95\% confidence level. To check accuracy of AAS, standards of all metals were prepared by dilution of $1000 \mathrm{mg} / \mathrm{L}$ certified standards solutions Fluka Kamica (Buchs, Switzerland) of corresponding metal ions with DDW and analyzed after every 10 samples. All chemicals used in digestion and analyses were of analytical grade, purchased from Merck.

2.5. Pollution Quantification. Pollution quantification was calculated through EF, PLI, and Plant BF.

2.5.1. Enrichment Factor (EF). Enrichment factor ratio was obtained from the MTM concentrations in the study area as reported by Shah et al. [1] and Muhammad et al. [2]:

$$
\mathrm{EF}=\frac{[\mathrm{C}] \text { trace metal }}{[\mathrm{C}] \text { background }} .
$$

2.5.2. Pollution Load Index (PLI). For entire sampling site, PLI has been determined as $n$th root of the product of the $n \mathrm{EF}$, accordingly to the equation adopted from Usero et al. [20]:

$$
\mathrm{PLI}=(\mathrm{EF} 1 \times \mathrm{EF} 2 \times \mathrm{EF} 3 \times \cdots \mathrm{EF} n)^{1 / n} .
$$

PLI provides a simple comparative means of MTM level in the study area. 


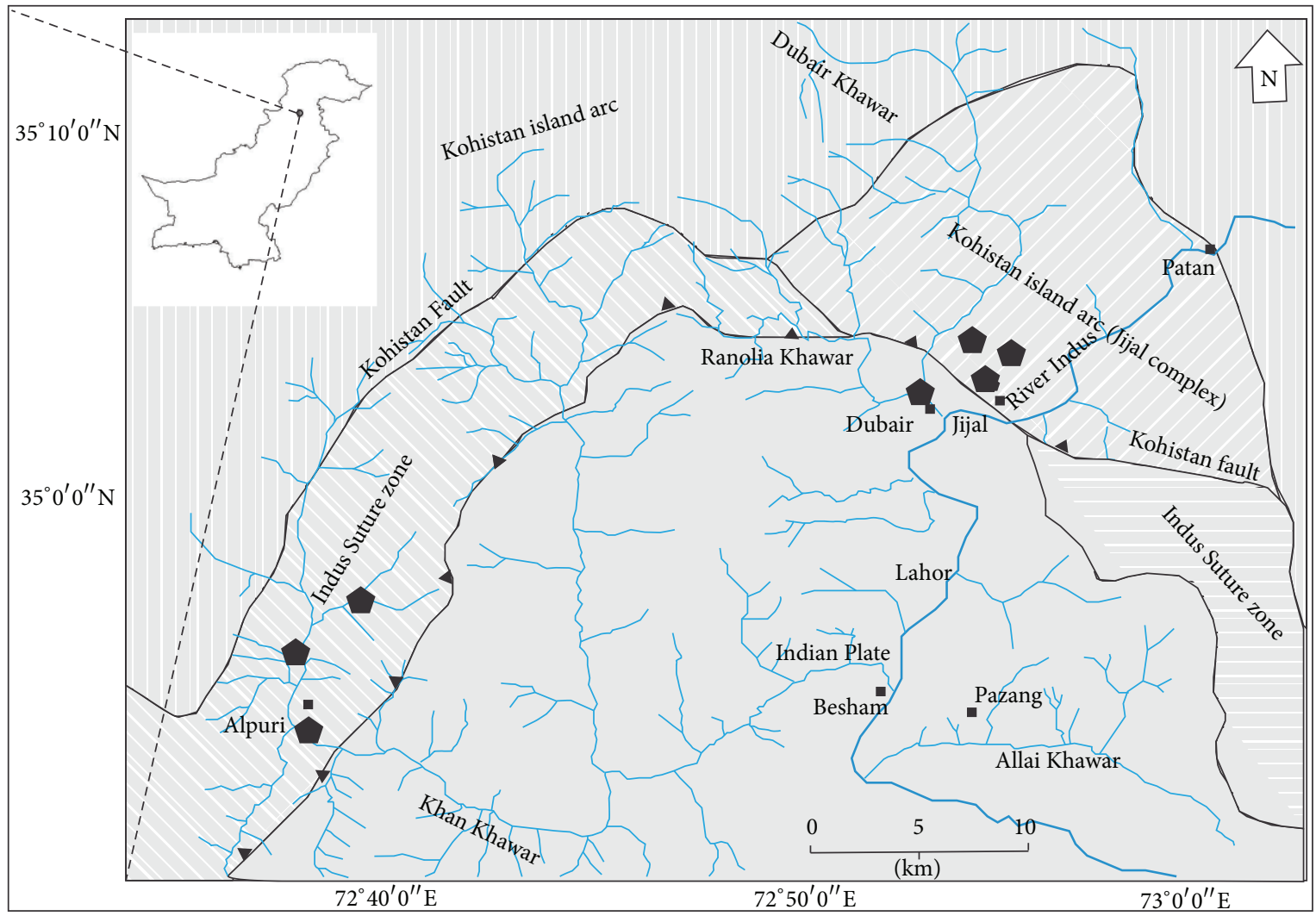

Towns
Chromite mines

Stream and river

FIGURE 1: Location map of the study area (modified after Dipietro et al., 1993 [15]).

2.5.3. Plants Bioaccumulation Factor (BF). Bioaccumulation factor is defined as the ability of a plant to accumulate MTM concentrations. Bioaccumulation factor was obtained from the ratio of MTM concentrations in plant and soil as reported by Rashed [13]:

$$
\mathrm{BF}=\frac{C \text { metal in Plant }}{C \text { metal in soil }} .
$$

2.6. Statistical Analyses. Statistical manipulations ranges, mean, and standard deviation were measured using Excel 2007 (Microsoft Office) and one-way ANOVA and correlation analysis using SPSS (17) statistical software.

\section{Results and Discussion}

\subsection{Soil}

3.1.1. Physiochemical Parameters. Soil $\mathrm{pH}$ mean values were found highest in Dubair (7.9), while they were lowest in Alpuri (6.9) of the study area. Electrical conductivity means values were found highest in Alpuri $(233 \mu \mathrm{S} / \mathrm{cm})$, while they were lowest in Dubair $(157 \mu \mathrm{S} / \mathrm{cm})$. Similarly, SOM was found highest in Alpuri (5.3), while it was lowest in Jijal
TABLE 1: Physical parameters in soil of the study area.

\begin{tabular}{lccccc}
\hline Parameters & Statistics & Dubair & Jijal & Alpuri & Reference \\
\hline \multirow{4}{*}{$\mathrm{pH}$} & Range & $6.8-8.9$ & $6.8-7.4$ & $5.8-8.0$ & $5.8-7.6$ \\
& Mean (SD $)$ & $7.9(0.6)$ & $7.2(0.2)$ & $6.9(0.6)$ & $6.8(0.5)$ \\
$\mathrm{EC}^{\mathrm{b}} \mu \mathrm{S} \mathrm{cm}^{-1}$ & Meange & $93-308$ & $114-318$ & $108-419$ & $61-163$ \\
& Range & $157(22)$ & $212(36)$ & $233(43)$ & $114(21)$ \\
$\mathrm{SOM}^{\mathrm{c}} \%$ & Mean (SD) & $4.2(1.3)$ & $3.6(0.9)$ & $5.3(1.3)$ & $3.3(1.1)$ \\
\hline
\end{tabular}

${ }^{a}$ Standard deviation.

${ }^{\mathrm{b}}$ Electrical conductivity.

${ }^{\mathrm{c}}$ Soil organic matter.

(3.6) (Table 1). Low $\mathrm{pH}$ and high organic matter may have attributed high soluble metallic ions concentration in soil at Alpuri site. As a result, Alpuri site has higher EC values as compared to other sites of the study area and background site. $\mathrm{pH}, \mathrm{EC}$, and SOM mean values of the study area were lower than those reported by Muhammad et al. [2] in soil of the PbZn sulfide terrain, northern Pakistan.

The concentrations of $\mathrm{Na}, \mathrm{K}, \mathrm{Ca}$ and $\mathrm{Mg}$ in soil ranged from 581 to 13870,2020 to 8035,1635 to 37305 , and 17125 to $77210 \mathrm{mg} / \mathrm{Kg}$, respectively (Figure 2). The concentrations of $\mathrm{Ca}$ and $\mathrm{Mg}$ in soil of these areas were found significantly 


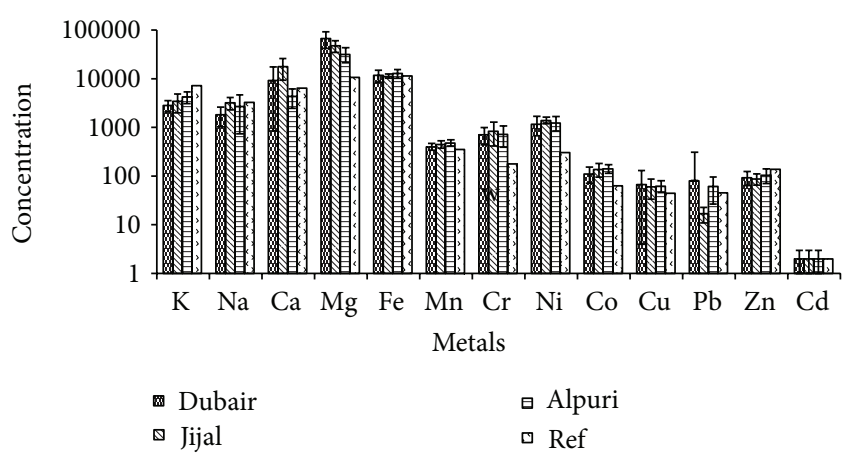

FIGURE 2: Physiochemical parameters in soil of the study area.

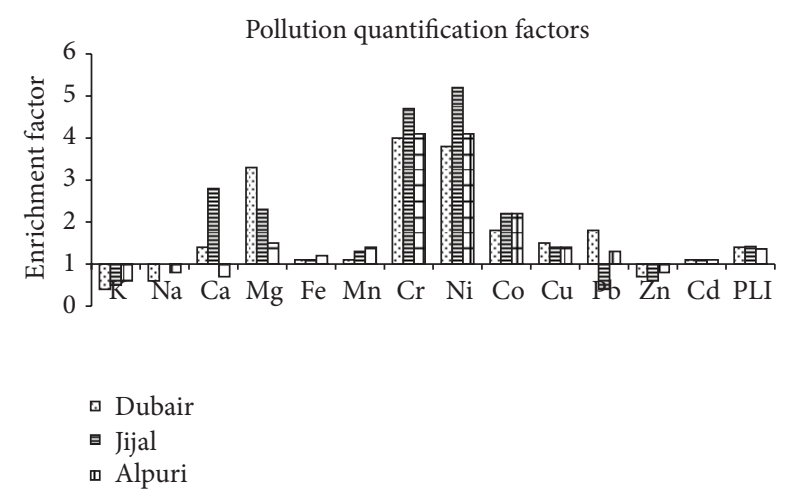

FIGURE 3: EF and PLI mean values of MTM in soil of the three sites in the study area.

$(P<.001)$ higher as compared to the background site. Similarly, Fe and $\mathrm{Mn}$ concentrations in soil ranged from 1180 to 16840 and 233 to $689 \mathrm{mg} / \mathrm{Kg}$, respectively (Figure 2). The concentrations of $\mathrm{Cr}, \mathrm{Ni}, \mathrm{Co}$ and $\mathrm{Cu}$ ranged from 60 to 2050, 93 to 2631,25 to 220 and, 10 to $296 \mathrm{mg} / \mathrm{Kg}$ and showed significantly $(P<.001)$ higher concentration as compared to the background site (Figure 2). In the study area, $\mathrm{Cr}$ and Ni mean concentrations were found in the order of Jijal > Alpuri > Dubair site, while those of $\mathrm{Co}$ and $\mathrm{Cu}$ were in the orders of Alpuri > Jijal > Dubair site and Dubair > Jijal > Alpuri site, respectively (Figure 2). Multifold higher concentrations of these metals in Jijal site can be attributed to the local mafic and ultramafic terrain and chromite mining [7]. Similarly, $\mathrm{Pb}, \mathrm{Zn}$, and $\mathrm{Cd}$ concentrations ranged from 17 to 240,88 to 170 , and 1 to $3 \mathrm{mg} / \mathrm{Kg}$, respectively (Figure 2). The concentrations of $\mathrm{Pb}, \mathrm{Zn}$, and $\mathrm{Cd}$ were almost similar to those of the background site. However, $\mathrm{Pb}$ and $\mathrm{Zn}$ concentrations were found higher than those reported by Yang et al. [9] in soil of mafic and ultramafic rocks in Mingora and Kabal areas.

\subsubsection{Metal Enrichment Factor (EF) and Pollution Load Index} (PLI). Figure 3 showed the soil EF of MTM collected along mafic and ultramafic terrain in the Kohistan region. Results showed that EF $>1$ for most of MTM such as Mg, Fe, and $\mathrm{Mn}$ in soil of the Jijal, Dubair, and Alpuri sites. However, $\mathrm{Ca}$ and $\mathrm{Mg}$ were enriched in soil of Jijal and Dubair, while those of Alpuri site depleted as compared to background site.
The values of $\mathrm{EF}$ for $\mathrm{K}$ and $\mathrm{Na}$ were found depleted in soil of these sites (Figure 3). Among the TM ( $\mathrm{Cr}$ and $\mathrm{Ni}), \mathrm{EF}>3.5$, while $\mathrm{Co}, \mathrm{Cu}$ and $\mathrm{Cd}$ showed $\mathrm{EF}>1$ in soil of the three sites (Figure 3). The $\mathrm{Pb}$ showed enrichment in soil of the Dubair and Alpuri areas and depletion in the Jijal area, while $\mathrm{Zn}$ revealed depletion in soil of all these sites. Based on Muller [21], classification in the Dubair site, soil contaminations with $\mathrm{Mg}, \mathrm{Cr}$ and $\mathrm{Ni}$ were classified as moderate to strongly polluted. In the Jijal site, soil contaminations with $\mathrm{Ca}, \mathrm{Mg}$, and Co were classified as moderately polluted and $\mathrm{Cr}$ and $\mathrm{Ni}$ as strongly polluted. Similarly, Alpuri site soil with Co as moderate polluted and $\mathrm{Cr}$ and $\mathrm{Ni}$ were classified as strongly polluted. In the study area, soil showed that $\mathrm{EF}$ values for $\mathrm{Mg}, \mathrm{Cr}, \mathrm{Ni}$, and $\mathrm{Co}$ were higher than those reported by Muhammad et al. [2] for these metals in soil of the $\mathrm{Pb}-\mathrm{Zn}$ sulfide terrain, northern Pakistan. Values of PLI $>1$ in three selected sites were in the order of Jijal $>$ Dubair $>$ Alpuri site (Figure 3). PLI values showed that Jijal site was highly contaminated which may be attributed due to chromite ore deposits and mining. Pollution load index values were found lower than that reported by Muhammad et al. [2] for soil in the Kohistan region, northern Pakistan and that by Rashed [13] for tailing deposit in Southeast Egypt.

\subsection{Plants}

3.2.1. Macro and Trace Metals (MTM). Table 2 summarizes the concentrations of MTM in plants along the mafic and ultramafic terrain and background sites. The concentrations of $\mathrm{Na}, \mathrm{K}, \mathrm{Ca}$ and $\mathrm{Mg}$ in plants ranged from 221 to 3257, 786 to 16044,1848 to 40915 , and 1293 to $46233 \mathrm{mg} / \mathrm{Kg}$, respectively (Table 2). Plant species that showed highest concentration of metals were Rumex hastatus (Na), Athyrium schimperi (K), Debregeasia salicifolia (Ca), and Plectranthus rugosus (Mg). Iron concentrations ranged from 114 to $11766 \mathrm{mg} / \mathrm{Kg}$ with highest in Olea ferruginea (Table 2). Plant species growing along mafic and ultramafic terrain are enriched with $\mathrm{Fe}$ [22]. Iron is one the essential nutrients in plant cell wall, chlorophyll, and protein. Deficiencies symptoms include necrotic lesions and interveinal chlorosis [23]. However, toxic effects include injured or necrotic spots on leaves and reduction of productivity $[24,25]$. Similarly, Mn concentrations ranged from 125 to $3154 \mathrm{mg} / \mathrm{Kg}$ with their highest in Rumex hastatus (Table 2). Manganese toxicity affects the absorption, translocation, enzyme activity, and utilization of metals (Ca, $\mathrm{Fe}, \mathrm{Mg}$, and $\mathrm{P}$ ), necrotic leaf spots, chlorosis in leaves, and reduction in growth and productivity $[26,27]$.

Copper concentrations ranged from 16 to $146 \mathrm{mg} / \mathrm{Kg}$ with an uppermost in Tagetes minuta and their lowest in Olea ferruganea (Table 2). In the study area, $\mathrm{Cu}$ concentration in plant species was higher than those reported by Shah et al. [1] in the mafic and ultramafic rocks flora of Mingora and Kabal areas. Copper critical concentrations ranged from 10 to $30 \mathrm{mg} / \mathrm{Kg}$ [28]. Deficiency effects are photosynthesis inhibition, twisting, stem bending, distortion of young leaves, pendulousness of lateral branches, and sterile pollen production [26]. However, toxicity includes reduction in plant biomass production [29]. Therefore, $\mathrm{Cu}$ concentrations may 


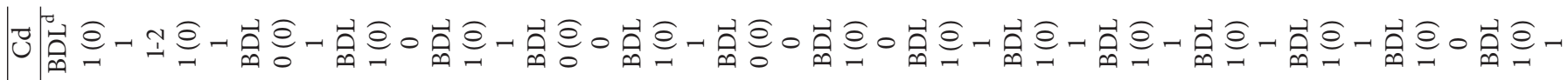

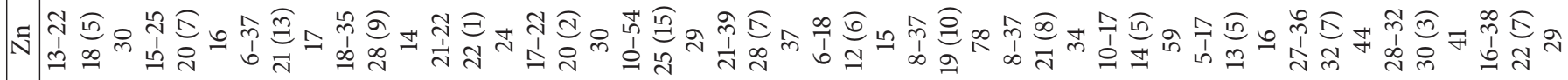

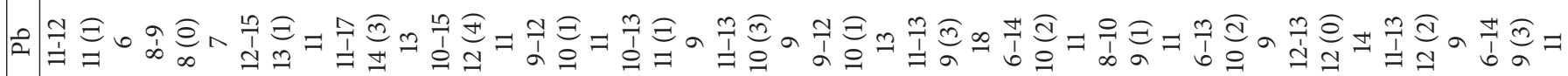

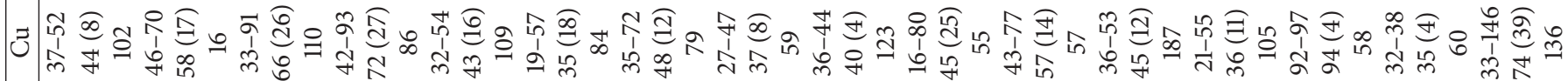

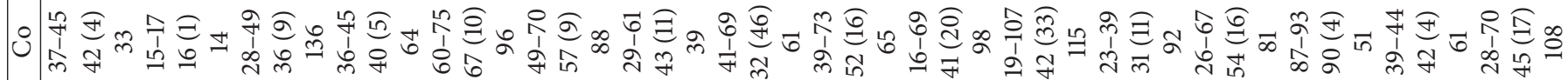
Z F ব

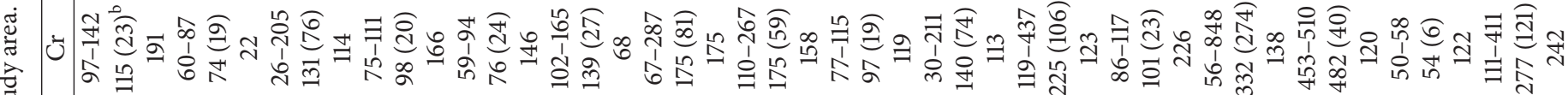

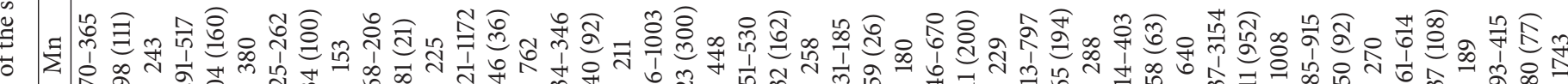

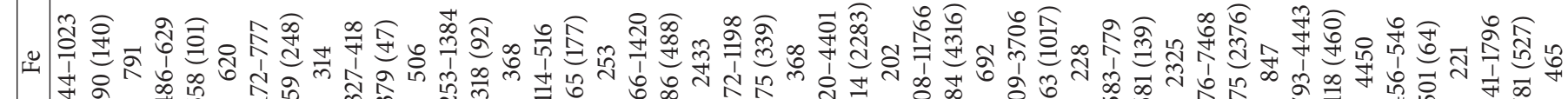

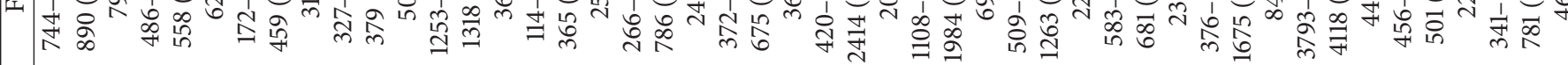

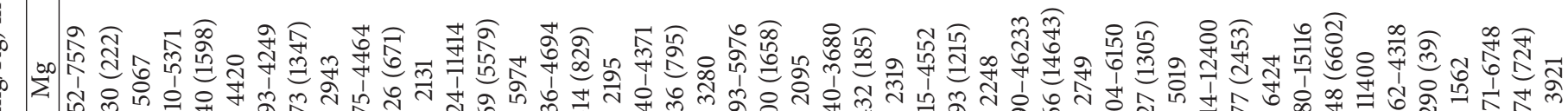
त्र

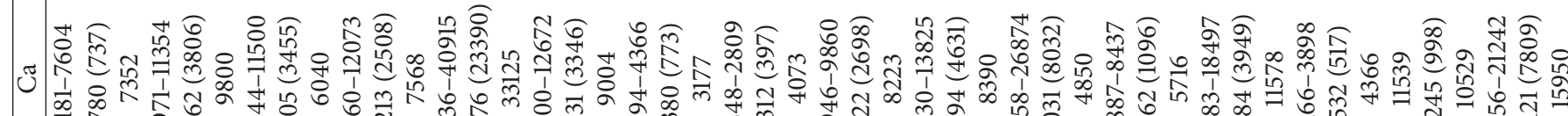

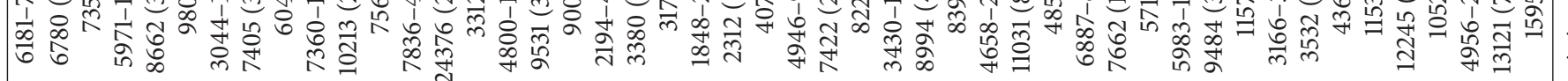

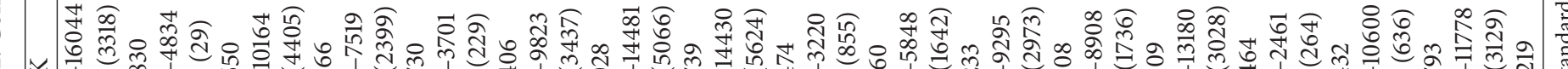

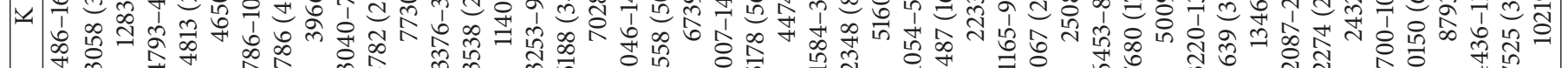

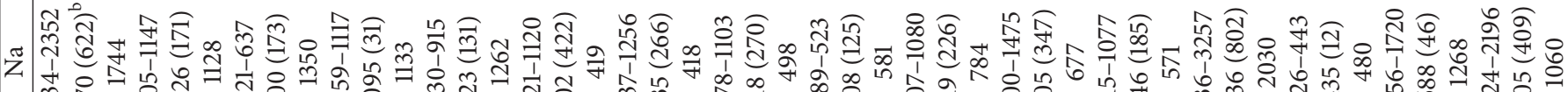

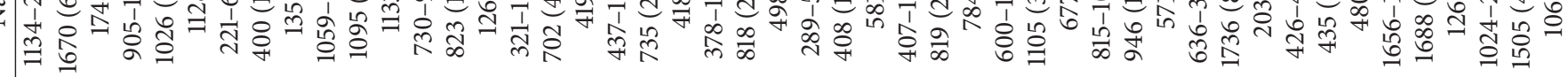

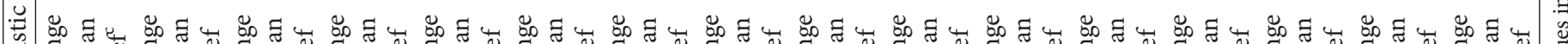

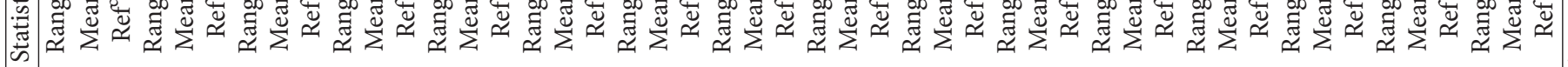

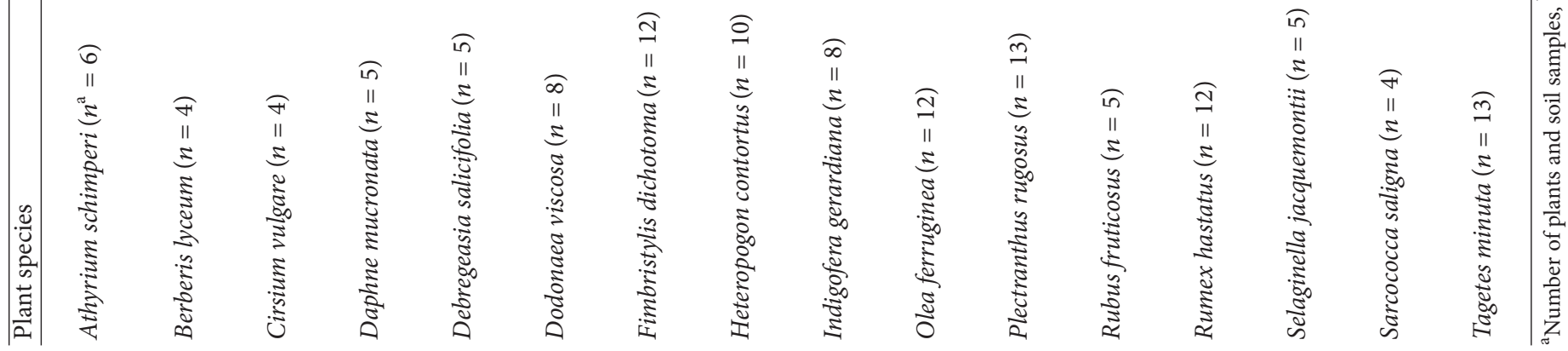


cause phytotoxicity in the selected plant species that showed higher concentrations. The concentrations of $\mathrm{Cr}$ ranged from 26 to $848 \mathrm{mg} / \mathrm{Kg}$ with a maximum in Rumex hastatus and minimum in Cirsium vulgare (Table 2). Generally, Cr toxicity in plants is reported from $>2 \mathrm{mg} / \mathrm{Kg}$ [28]. Therefore, $\mathrm{Cr}$ concentrations in all selected plants species are multiple times higher than the safe limits, and due to which this Cr level could be hazardous for local community as reported by Shah et al. $[7,9]$. However, $\mathrm{Cr}$ concentrations in the study area were found lower $(1958 \mathrm{mg} / \mathrm{Kg})$ than those reported by Reddy et al. [30] in plant species growing on mining dump from India. Nickel concentrations ranged from 84 to $2049 \mathrm{mg} / \mathrm{Kg}$ with a highest in Plectranthus rugosus and lowest in Olea ferruganea (Table 2). Previously, Ni accumulation has been reported in many flora of serpentine soil $[31,32]$. The concentrations of $\mathrm{Ni}$ in plant species were found much lower (up to $35600 \mathrm{mg} / \mathrm{Kg}$ ) than those reported by Reeves and Adigüzel [33] growing on the serpentine soil. Generally, the safe limit of Ni varies widely among plant species and therefore, ranging from 10$30 \mathrm{mg} / \mathrm{Kg}$ [25]. Among selected species, some of the plants showed multifold higher concentrations and may cause toxic affects in these plants. Nickel is an essential micronutrient in very small amounts as reported by Wood et al. [34]. Higher concentrations are toxic and may adversely affect the root and shoot growth and significant loss of chlorophyll content $[35,36]$. Cobalt concentrations ranged from 15 to $107 \mathrm{mg} / \mathrm{Kg}$ with a highest in Plectranthus rugosus and lowest in Berberis lyceum (Table 2). The safe limits of Co ranged from 10 to $20 \mathrm{mg} / \mathrm{Kg}$. Li et al. [37] reported the phytotoxicity effects of Co in shoot growth and biomass of plant species (Hordeum vulgare, Brassica napus, and L. esculentum).

Lead concentrations ranged from 6 to $17 \mathrm{mg} / \mathrm{Kg}$ with a highest concentration in Daphne mucronata and lowest in Olea ferruganea (Table 2). Generally, the $\mathrm{Pb}$ concentrations ranging from 2 to $6 \mathrm{mg} / \mathrm{Kg}$ are sufficient, while safe agriculture limit is $10 \mathrm{mg} / \mathrm{Kg}$ [38]. Lead concentrations in $70 \%$ of selected plant species exceeded the limits causing phytotoxicity. However, the $\mathrm{Pb}$ concentrations in plant species were found much lower than those reported by Sagiroglu et al. [39] growing (up to $1985 \mathrm{mg} / \mathrm{Kg}$ ) in the Keban mining district, Turkey. The concentrations of $\mathrm{Zn}$ ranged from 6 to $54 \mathrm{mg} / \mathrm{Kg}$ with a highest in Fimbristylis dichotoma and lowest in Cirsium vulgarea (Table 2). Toxic limit of $\mathrm{Zn}$ in majority of the plant species is $500 \mathrm{mg} / \mathrm{Kg}$ [24]. However, plants with $\mathrm{Zn}<20 \mathrm{mg} / \mathrm{Kg}$ are considered to be $\mathrm{Zn}$ deficient [40]. Therefore, majority of plant species were considered to be deficient in $\mathrm{Zn}$ contents. Zinc is one of the required metals in a specific amount; however, its high concentration may produce toxic effects in living organism $[1,2]$. Cadmium concentrations ranged from 0 to $2 \mathrm{mg} / \mathrm{Kg}$ with a highest in Berberis lyceum and lowest in Cirsium vulgarea (Table 2). Cadmium concentrations in majority of plant species were equal to that of background site. However, $20 \%$ of the plant species showed Cd concentrations below detection limits. Cadmium may cause toxicity in majority of the plant species when its concentration is above $2 \mathrm{mg} / \mathrm{Kg}$ [24]. In plants, $\mathrm{Cd}$ accumulation causes growth inhibition, browning of root tips, chlorosis, water and nutrient uptake, reduction in photosynthesis, DNA repair inhibition and finally death [36].
Generally, some of the selected wild plant species showed higher metal accumulations. Plant species such as Selaginella jacquemontii showed higher accumulations for $\mathrm{Fe}(4118 \mathrm{mg} / \mathrm{Kg}), \mathrm{Mn}(850 \mathrm{mg} / \mathrm{Kg}), \mathrm{Cr}(482 \mathrm{mg} / \mathrm{Kg}), \mathrm{Ni}$ (1638 mg/Kg), Co (90 mg/Kg), and Cu (94 mg/Kg). Similarly, the plant species that accumulated higher metal accumulation were Rumex hastatus: Fe (1675 mg/Kg), Mn (811 mg/Kg), $\mathrm{Cr}(332 \mathrm{mg} / \mathrm{Kg})$, and $\mathrm{Ni}(479 \mathrm{mg} / \mathrm{Kg})$; Plectranthus rugosus: $\mathrm{Fe}(1263 \mathrm{mg} / \mathrm{Kg}), \mathrm{Mn}(365 \mathrm{mg} / \mathrm{Kg}), \mathrm{Cr}(225 \mathrm{mg} / \mathrm{Kg})$, and $\mathrm{Ni}$ (658 mg/Kg); Debregeasia salicifolia: $\mathrm{Fe}(1318 \mathrm{mg} / \mathrm{Kg}), \mathrm{Mn}$ (1146 mg/Kg), Ni (428 mg/Kg), and Co (67 mg/Kg); and Olea ferruganea: $\mathrm{Mn}(1984 \mathrm{mg} / \mathrm{Kg})$ as compared to other selected plants of the study area.

Considering the maximum permissible limits of heavy metal in plants, this study revealed that wild flora has accumulated higher concentrations of the $\mathrm{Fe}, \mathrm{Mn}, \mathrm{Cu}$, and $\mathrm{Pb}$. Therefore, these metals may have adverse effects on flora of the study area $[7,26,27,41]$. Similarly, Ni and Cr higher concentrations in plant species may lead to phytotoxicity. Enrichment of these metals in wild flora could be a serious threat to community of the area $[1,7,9,10]$. However, Mewis et al. [42] reported that for detoxification of metal stress and competition the accumulator plant species activate the defense mechanism.

3.2.2. Metal Enrichment Factor (EF) and Bioaccumulation Factor (BF). Table 3 summarizes the EF, BF of MTM in plants collected from the mafic and ultramafic terrain in the Kohistan region. Among the selected plant species, Berberis lycium showed multifold concentrations of metals such as $\mathrm{Cr}$ (3.4), Ni (8.1), and Cu (3.6), while Debregeasia salicifolia and Heteropogon contortus for Fe (3.6 and 12), similarly, Olea ferrugainea for $\mathrm{Mg}$ (4.7) and $\mathrm{Fe}$ (5.5), while Rumex hastatus for Mn (3.1), $\mathrm{Cr}$ (4.0) and $\mathrm{Ni}$ (4.7) as shown in the Table 3. This multifold higher EF of MTM in plants of mafic and ultramafic terrain as compared to that of background site can be attributed due to the serpentine soil which is generally rich in these metals especially $\mathrm{Fe}, \mathrm{Mg}, \mathrm{Cr}$, and $\mathrm{Ni}$ $[7,9]$. Plant BF values were highest in Dodonaea viscose, Fimbristylis dichotoma $(\mathrm{K}=2.0)$, Sarcococca saligna (Ca $=2.9)$, Debregeasia salicifolia $(\mathrm{Mn}=2.5)$, and Selaginella jacquemontii $(\mathrm{Ni}=1.3, \mathrm{Cu}=2.0)$ as shown in Table 3 .

3.3. Statistical Analyses. One-way ANOVA results revealed that some of metals $(\mathrm{Ca}, \mathrm{Mg}, \mathrm{Cr}, \mathrm{Ni}, \mathrm{Co}$, and $\mathrm{Cu}$ ) have significantly $(P<.001)$ higher concentrations in the Dubair, Jijal, and Alpuri sites of mafic and ultramafic terrain as compared to the background site. These multifold higher concentrations of metals can be attributed to the mafic and ultramafic terrain and chromite mining in the area $[1,7,9$, 10]. Inter-relationship of physiochemical parameters in soil of the study area is summarized in Table 4. Physiochemical parameters showed that some pairs in soil have higher correlations such as $\mathrm{pH}-\mathrm{Mg}(r=0.692)$, Fe-Co $(r=0.514)$, Cr-Ni $(r=0.565)$, and Cr-Co $(r=0.504)$ as shown in Table 4. Similarly, in plants, some elemental pairs also showed higher correlation like Na-K $(r=0.541)$, Mn-Ni $(r=0.533)$, Cr$\mathrm{Ni}(r=0.516), \mathrm{Cr}-\mathrm{Co}(r=0.522)$, and Ni-Co $(r=0.545)$ 
TABLE 3: EF and PLI of MTM in plant species of the study area $\left(n^{\mathrm{a}}=126\right)$.

\begin{tabular}{|c|c|c|c|c|c|c|c|c|c|c|c|c|c|c|c|c|c|c|c|c|c|c|c|c|c|c|}
\hline \multirow[t]{2}{*}{$\mathrm{Pl}$} & \multicolumn{2}{|c|}{$\mathrm{Na}$} & \multicolumn{2}{|c|}{ K } & \multicolumn{2}{|c|}{$\mathrm{Ca}$} & \multicolumn{2}{|c|}{$\mathrm{Mg}$} & \multicolumn{2}{|c|}{$\mathrm{Fe}$} & \multicolumn{2}{|c|}{$\mathrm{Mn}$} & \multicolumn{2}{|c|}{$\mathrm{Cr}$} & \multicolumn{2}{|c|}{$\mathrm{Ni}$} & \multicolumn{2}{|c|}{ Co } & \multicolumn{2}{|c|}{$\mathrm{Cu}$} & \multicolumn{2}{|c|}{$\mathrm{Pb}$} & \multicolumn{2}{|c|}{$\mathrm{Zn}$} & \multicolumn{2}{|c|}{$\mathrm{Cd}$} \\
\hline & & & $\mathrm{EF}$ & $\mathrm{BF}$ & EF & $\mathrm{F}$ & 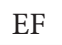 & $\mathrm{BF}$ & $F$ & F & $\mathrm{EF}$ & $\mathrm{F}$ & F & $\mathrm{BF}$ & E. & $\mathrm{BF}$ & $\mathrm{EF}$ & $\mathrm{BF}$ & $\mathrm{EF}$ & BF & $\mathrm{EF}$ & BF & EF & $\mathrm{BF}$ & $\mathrm{EF}$ & . \\
\hline & & & & & & & & & & & & & & & & & & & & & - & & & & & - \\
\hline & & & & & & & 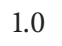 & 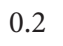 & & & & & 4 & & & & & & 6 & 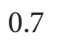 & 1. & & 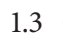 & & 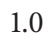 & 0.5 \\
\hline & & & 0 & & & & 1 & 0.0 & & & 0.9 & & & 0.2 & & 1 & 0.3 & & 0.6 & 1.6 & 1.2 & & 1.2 & & 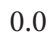 & 0.0 \\
\hline & & & & 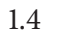 & 3 & & 1.8 & 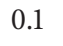 & & & & & 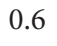 & & & 3 & & & & & & & & & & 5 \\
\hline & & & & & & & & 0 & & & & & & & & & 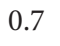 & & & & & & & & & 0. \\
\hline & & & 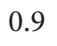 & 0 & 1 & & 6 & 0.2 & & & 1. & & 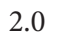 & 5 & & 2 & 0.6 & 0.9 & 0.4 & 2 & 0.9 & & 0.7 & 4 & 5 & 0.0 \\
\hline & & & 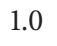 & & 1 & 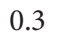 & 0 & 1 & & & 0 & 0 & .0 & & & & 1.1 & 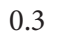 & 0.6 & 8 & 1.2 & & 0.9 & & .0 & 0. \\
\hline & & & & & 6 & & 1 . & 0.1 & & & 1.3 & & 1.1 & 0.3 & & & 0.5 & & 0.6 & 7 & 1.1 & & 0.8 & & & 0.0 \\
\hline & & & 0.5 & 5 & 9 & 0.8 & 1.5 & 0.1 & 12.0 & & 0.9 & 0.4 & 0.8 & 0.1 & 1.8 & 2 & 0.8 & 0.4 & 0.3 & 0.4 & 0.8 & & 0.8 & & & 0.3 \\
\hline & 1. & & 6 & 0 & 1 & 1.3 & 1.5 & 0.1 & & 2 & 1.4 & 0.7 & 1.2 & 0.2 & 1.4 & 0.2 & 0.4 & 0.3 & 0.8 & 0.6 & 0.5 & & 0.2 & 0.2 & .0 & 0.5 \\
\hline & & & 0 & 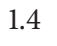 & 3 & 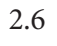 & 4.7 & 0.2 & & 1 & 1.3 & 0.8 & 1.8 & 0.3 & 2.3 & 5 & 0.4 & 0.3 & 1.0 & 1.1 & 0.9 & & 0.6 & 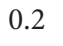 & .0 & .0 \\
\hline & & & & & & & 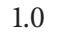 & 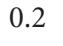 & & & & & & & & & & & & & 0.8 & & 0.2 & & . & J.3 \\
\hline & & & 0.5 & 2.0 & & & 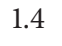 & 0.1 & & & 0.8 & & & 0.3 & & 0.4 & 0.7 & & 0.3 & 0.5 & 1.1 & & 0.8 & 0.2 & 政 & 0. \\
\hline & & & 0. & 0.7 & & & 0.9 & 0.2 & & & 3. & & 4.0 & 0.7 & & & 1.8 & 0.9 & 1.6 & .0 & 0.9 & & 0.7 & 0 & .0 & 0.5 \\
\hline & i 1.3 & & 1.2 & & & 2.9 & 2. & 0.1 & & & 2. & & & & & & 0.7 & & 0.6 & & 1.3 & & 0.7 & & & 0.3 \\
\hline a & 1.4 & 0.5 & 0.7 & 2.4 & 0.8 & 0.7 & 1.6 & 0.1 & 1.7 & 0 & 0.2 & 0.5 & 1.1 & 0.4 & 1.4 & 0.3 & 0.4 & 0.4 & 0.5 & 1.2 & 0.8 & - & 0.8 & 0.2 & .0 & .0 \\
\hline
\end{tabular}

${ }^{\mathrm{a}}$ Enrichment factor.

${ }^{\mathrm{b}}$ Bioaccumulation factor.

${ }^{\mathrm{c}}$ Number of plants samples.

TABLE 4: The Pearson correlation of physiochemical parameters in soil $(n=126)$.

\begin{tabular}{|c|c|c|c|c|c|c|c|c|c|c|c|c|c|c|c|c|}
\hline Parameters & $\mathrm{s} \quad \mathrm{pH}$ & $\mathrm{EC}$ & SOM & $\mathrm{Na}$ & $\mathrm{K}$ & $\mathrm{Ca}$ & $\mathrm{Mg}$ & $\mathrm{Fe}$ & $\mathrm{Mn}$ & $\mathrm{Cr}$ & $\mathrm{Ni}$ & Co & $\mathrm{Cu}$ & $\mathrm{Pb}$ & $\mathrm{Zn}$ & $\mathrm{Cd}$ \\
\hline $\mathrm{pH}$ & 1.000 & & & & & & & & & & & & & & & \\
\hline EC & -0.329 & 1.000 & & & & & & & & & & & & & & \\
\hline SOM & -0.234 & 0.252 & 1.000 & & & & & & & & & & & & & \\
\hline $\mathrm{Na}$ & -0.298 & 0.188 & 0.099 & 1.000 & & & & & & & & & & & & \\
\hline $\mathrm{K}$ & -0.505 & 0.269 & 0.311 & 0.289 & 1.000 & & & & & & & & & & & \\
\hline $\mathrm{Ca}$ & 0.195 & -0.087 & -0.150 & 0.061 & -0.115 & 1.000 & & & & & & & & & & \\
\hline $\mathrm{Mg}$ & 0.692 & -0.313 & -0.358 & -0.365 & -0.624 & 0.091 & 1.000 & & & & & & & & & \\
\hline $\mathrm{Fe}$ & -0.147 & -0.144 & 0.096 & 0.168 & 0.245 & -0.037 & -0.040 & 1.000 & & & & & & & & \\
\hline $\mathrm{Mn}$ & -0.131 & 0.303 & 0.376 & 0.154 & 0.283 & -0.003 & -0.343 & 0.209 & 1.000 & & & & & & & \\
\hline $\mathrm{Cr}$ & -0.015 & -0.174 & -0.044 & -0.011 & -0.037 & 0.361 & 0.043 & 0.491 & -0.003 & 1.000 & & & & & & \\
\hline $\mathrm{Ni}$ & 0.305 & 0.078 & 0.226 & -0.312 & -0.227 & -0.476 & 0.378 & 0.140 & 0.304 & 0.565 & 1.000 & & & & & \\
\hline Co & -0.403 & 0.093 & 0.077 & 0.140 & 0.147 & -0.036 & -0.200 & 0.514 & 0.234 & 0.504 & 0.098 & 1.000 & & & & \\
\hline $\mathrm{Cu}$ & -0.065 & -0.031 & -0.015 & 0.091 & 0.242 & 0.208 & -0.182 & 0.352 & -0.052 & 0.560 & -0.215 & 0.209 & 1.000 & & & \\
\hline $\mathrm{Pb}$ & -0.047 & 0.039 & -0.007 & 0.010 & -0.082 & -0.191 & 0.311 & 0.080 & -0.079 & -0.079 & 0.041 & 0.040 & -0.102 & 1.000 & & \\
\hline $\mathrm{Zn}$ & -0.138 & 0.263 & 0.139 & 0.019 & 0.211 & -0.179 & -0.151 & 0.369 & 0.249 & 0.090 & 0.041 & 0.073 & -0.006 & 0.051 & 1.000 & \\
\hline $\mathrm{Cd}$ & -0.165 & 0.048 & -0.184 & 0.049 & 0.119 & 0.111 & -0.042 & 0.315 & -0.208 & 0.156 & -0.211 & 0.173 & 0.464 & 0.031 & 0.253 & 1.000 \\
\hline
\end{tabular}

Bold correlation is significant at the 0.01 level (2-tailed).

Italic correlation is significant at the 0.05 level (2-tailed).

as shown in Table 5. Interelement relationships are providing interesting information on elements sources and pathways [43]. Correlation metrics showed these relationships were not highly significant in soil and plants, which may be due to the different properties of soil and the physiologies of plant species [7, 9]. These weak correlations of physiochemical parameters in soil and plants can be attributed to the variable concentrations of these parameters in soil of the area and variation in plant uptake $[2,10]$.

\section{Conclusions}

In the study area, natural processes such as weathering and erosion and anthropogenic processes including mining have caused metals contamination in soil and plants. Pollution indices (EF and PLI) suggested that the Jijal soil was strongly polluted (EF > 3.5) with $\mathrm{Ni}$ and Cr. Generally, some of the selected wild plant species showed higher metal accumulation. Plant species that revealed significant higher 
TABLE 5: The Pearson correlation of MTM in plants $(n=126)$.

\begin{tabular}{|c|c|c|c|c|c|c|c|c|c|c|c|c|c|}
\hline Parameters & $\mathrm{Na}$ & $\mathrm{K}$ & $\mathrm{Ca}$ & $\mathrm{Mg}$ & $\mathrm{Fe}$ & $\mathrm{Mn}$ & $\mathrm{Cr}$ & $\mathrm{Ni}$ & Co & $\mathrm{Cu}$ & $\mathrm{Pb}$ & $\mathrm{Zn}$ & $\mathrm{Cd}$ \\
\hline $\mathrm{Na}$ & 1.000 & & & & & & & & & & & & \\
\hline K & 0.541 & 1.000 & & & & & & & & & & & \\
\hline $\mathrm{Ca}$ & 0.256 & -0.058 & 1.000 & & & & & & & & & & \\
\hline $\mathrm{Mg}$ & 0.265 & 0.123 & 0.308 & 1.000 & & & & & & & & & \\
\hline $\mathrm{Fe}$ & -0.121 & -0.167 & 0.110 & 0.104 & 1.000 & & & & & & & & \\
\hline $\mathrm{Mn}$ & 0.454 & 0.201 & 0.171 & 0.158 & 0.151 & 1.000 & & & & & & & \\
\hline $\mathrm{Cr}$ & 0.197 & -0.037 & 0.101 & 0.316 & 0.186 & 0.103 & 1.000 & & & & & & \\
\hline $\mathrm{Ni}$ & 0.143 & 0.015 & 0.111 & 0.413 & 0.343 & 0.533 & 0.516 & 1.000 & & & & & \\
\hline Co & -0.025 & -0.205 & 0.385 & 0.205 & 0.413 & 0.178 & 0.522 & 0.545 & 1.000 & & & & \\
\hline $\mathrm{Cu}$ & 0.003 & -0.067 & 0.012 & 0.118 & 0.222 & -0.058 & 0.555 & 0.193 & 0.044 & 1.000 & & & \\
\hline $\mathrm{Pb}$ & -0.075 & -0.124 & 0.324 & 0.103 & 0.072 & 0.079 & -0.057 & 0.137 & 0.298 & 0.160 & 1.000 & & \\
\hline $\mathrm{Zn}$ & -0.023 & -0.098 & 0.020 & 0.040 & 0.209 & -0.069 & 0.164 & 0.066 & 0.124 & 0.397 & 0.238 & 1.000 & \\
\hline $\mathrm{Cd}$ & 0.251 & 0.019 & 0.073 & 0.227 & 0.134 & 0.177 & 0.226 & 0.210 & 0.135 & 0.038 & 0.014 & 0.059 & 1.000 \\
\hline
\end{tabular}

Bold correlation is significant at the 0.01 level (2-tailed).

Italic correlation is significant at the 0.05 level (2-tailed).

accumulations were Selaginella jacquemontii for (Fe, Mn, $\mathrm{Cr}, \mathrm{Ni}, \mathrm{Co}$, and $\mathrm{Cu}$ ); Rumex hastatus (Fe, $\mathrm{Mn}, \mathrm{Cr}, \mathrm{Ni}$ ); and Plectranthus rugosus ( $\mathrm{Fe}, \mathrm{Mn}, \mathrm{Cr}$, and $\mathrm{Ni}$ ) as compared to other selected plant of the study area. Therefore, this study suggests that these wild plant species may be used for land reclamations and mineral prospecting.

\section{Acknowledgments}

This research work was financially supported by the Higher Education Commission (HEC), Islamabad, Pakistan, in the form of a PhD scholarship to the first author. Director NCE in Geology, University of Peshawar, Pakistan, is thanked for providing the field and analytical facilities for acquisition of the chemical data. Professor Dr. Abdur Rasheed, Botany Department, Mr. Muhammad Waqas Javed NCE in Geology, University of Peshawar, Mr. Niaz Muhammad Legal Officer, and Taj Muhammad, Pakistan Institute of Parliamentary Services (PIPS), are highly acknowledged for plant identification, GIS map development, and proof reading, respectively.

\section{References}

[1] M. T. Shah, S. Begum, and S. Khan, "Pedo and biogeochemical studies of mafic and ultramfic rocks in the Mingora and Kabal areas, Swat, Pakistan," Environmental Earth Sciences, vol. 60, no. 5, pp. 1091-1102, 2010.

[2] S. Muhammad, M. T. Shah, and S. Khan, "Heavy metal concentrations in soil and wild plants growing around $\mathrm{Pb}-\mathrm{Zn}$ sulfide terrain in the Kohistan region, northern Pakistan," Microchemical Journal, vol. 99, no. 1, pp. 67-75, 2011.

[3] S. Muhammad, M. T. Shah, and S. Khan, "Health risk assessment of heavy metals and their source apportionment in drinking water of Kohistan region, northern Pakistan," Microchemical Journal, vol. 98, no. 2, pp. 334-343, 2011.

[4] N. M. Abdel-Monem, A. M. Abdel-Azeem, E. H. El-Ashry, D. A. Ghareeb, and A. Nabil-adam, "Pretreatment Hepatoprotective effect of the marine fungus derived from sponge on hepatic toxicity induced by heavy metals in rats," BioMed Research International, vol. 2013, Article ID 510879, 15 pages, 2013.

[5] M. A. Hossain, P. Piyatida, J. A. T. Silva, and M. Fujita, "Molecular mechanism of heavy metal toxicity and tolerance in plants: central role of glutathione in detoxification of reactive oxygen species and Methylglyoxal and in heavy metal chelation," Journal of Botany, vol. 2012, Article ID 872875, 37 pages, 2012.

[6] V. Angelova, R. Ivanova, V. Delibaltova, and K. Ivanov, "Bioaccumulation and distribution of heavy metals in fibre crops (flax, cotton and hemp)," Industrial Crops and Products, vol. 19, no. 3, pp. 197-205, 2004.

[7] M. T. Shah, J. Ara, S. Muhammad, S. Khan, S. A. Asad, and L. Ali, "Potential heavy metal accumulation of indigenous plant species along the mafic and ultramafic terrain in the Mohmand agency, Pakistan," Clean-Soil, Air, Water, 2013.

[8] H. Lim, J. Lee, H. Chon, and M. Sager, "Heavy metal contamination and health risk assessment in the vicinity of the abandoned Songcheon Au-Ag mine in Korea," Journal of Geochemical Exploration, vol. 96, no. 2-3, pp. 223-230, 2008.

[9] Z. Yang, W. Lu, Y. Long, X. Bao, and Q. Yang, "Assessment of heavy metals contamination in urban topsoil from Changchun City, China," Journal of Geochemical Exploration, vol. 108, no. 1, pp. 27-38, 2011.

[10] A. Naz, S. Khan, M. Qasim, S. Khalid, S. Muhammad, and M. Tariq, "Metals toxicity and its bioaccumulation in purslane seedlings grown in controlled environment," Natural Science, vol. 5, no. 5, pp. 573-579, 2013.

[11] M. T. Shah, Q. Kifayattullah, and M. Arfan, "Pedo and biogeochemical study of Zinc-Lead deposits of the Besham area, northern Pakistan: its implication in mineral exploration and environmental degradation," Environmental Geology, vol. 45, no. 4, pp. 544-549, 2004.

[12] S. Khan, A. Naz, M. Asim, S. A. Ahmad, S. Yousaf, and S. Muhammad, "Toxicity and bioaccumulation of heavy metals in spinach seedlings grown on freshly contaminated soil," Pakistan Journal of Botany, vol. 45, supplement 1, pp. 501-508, 2013.

[13] M. N. Rashed, "Monitoring of contaminated toxic and heavy metals, from mine tailings through age accumulation, in soil and some wild plants at Southeast Egypt," Journal of Hazardous Materials, vol. 178, no. 1-3, pp. 739-746, 2010. 
[14] S. Muhammad, M. Tahir Shah, and S. Khan, "Arsenic health risk assessment in drinking water and source apportionment using multivariate statistical techniques in Kohistan region, northern Pakistan," Food and Chemical Toxicology, vol. 48, no. 10, pp. 2855-2864, 2010.

[15] J. A. Y. Dipietro, K. R. Pogue, R. D. Lawrence, M. S. Baig, A. Hussain, and I. Ahmad, "Stratigraphy south of the Main Mantle Thrust, Lower Swat, Pakistan," in Himalayan Tectonics, P. J. Treloar and M. P. Searle, Eds., vol. 45, pp. 207-220, Geological Society, London, UK, 1993.

[16] D. J. Miller, R. R. Loucks, and M. Ashraf, "Platinum-group metals mineralization in the Jijal layered ultramafic-mafic complex, Pakistani Himalayas," Economic Geology, vol. 86, no. 5, pp.10931102, 1991.

[17] J. Ryan, G. Estefan, and A. Rashid, Soil and Plant Analysis Laboratory Manual, Interaction Center for Agricultural Research in the Dry Areas (ICARDA), Aleppo, Syria, 2nd edition, 2001.

[18] M. Das and S. K. Maiti, "Comparison between availability of heavy metals in dry and wetland tailing of an abandoned copper tailing pond," Environmental Monitoring and Assessment, vol. 137, no. 1-3, pp. 343-350, 2008.

[19] M. E. Konen, P. M. Jacobs, C. Lee Burras, B. J. Talaga, and J. A. Mason, "Equations for predicting soil organic carbon using loss-on-ignition for north central U.S. soils," Soil Science Society of America Journal, vol. 66, no. 6, pp. 1878-1881, 2002.

[20] U. Usero, A. Garcia, and J. Fraidias, Calidad de las Aguas y Sedimentos del Litoral Andaluz, Junta de Andalucía, Consejería de Medio Ambiente, Universidad de Sevilla, Sevilla, Spain, 2000.

[21] G. Muller, "Index of geoaccumulation in sediments of the Rhine River," GeoJournal, vol. 2, no. 3, pp. 108-118, 1969.

[22] R. D. Reeves and A. J. M. Baker, "Metal-accumulating plants," in Phytoremediation of Toxic Metals: Using Plants to Clean up the Environment, I. Raskin and B. D. Ensley, Eds., pp. 193-229, John Wiley \& Sons, New York, NY, USA, 2000.

[23] R. W. Bell and B. Dell, Micronutrients for Sustainable Food, Feed, Fibre and Bioenergy Production, IFA, Paris, France, 2008.

[24] WHO/FAO, "Joint FAO/WHO food standard programme codex alimentarius commission 13th session," ALINORM $07 / 30 / 13$, Report of the thirty eight session of the codex committee on food hygiene, Houston, Tex, USA, 2007.

[25] J. G. Genon, N. de Hepcee, J. E. Duffy, B. Delvaux, and P. A. Hennebert, "Iron toxicity and other chemical soil constraints to rice in highland swamps of Burundi," Plant and Soil, vol. 166, no. 1, pp. 109-115, 1994.

[26] H. Marschner, Mineral Nutrition of Higher Plants, Academic Press, London, UK, 2nd edition, 1995.

[27] R. Millaleo, M. Reyes-Díaz, A. G. Ivanov, M. L. Mora, and M. Alberdi, "Manganese as essential and toxic element for plants: transport, accumulation and resistance mechanisms," Journal of Soil Science and Plant Nutrition, vol. 10, no. 4, pp. 476-494, 2010.

[28] A. Kabata-Pendias, Trace Elements in Soil and Plants, vol. 4, Taylor \& Francis, london, UK; CRC Press, New York, NY, USA, 2011.

[29] R. Ghasemi, S. M. Ghaderian, and U. Krämer, "Interference of nickel with copper and iron homeostasis contributes to metal toxicity symptoms in the nickel hyperaccumulator plant Alyssum inflatum," New Phytologist, vol. 184, no. 3, pp. 566-580, 2009.

[30] L. C. S. Reddy, K. V. R. Reddy, S. K. Humane, and B. Damodaram, "Accumulation of chromium in certain plant species growing on mine dump from Byrapur, Karnataka, India,"
Research Journal of Chemical Sciences, vol. 2, no. 12, pp. 17-20, 2012.

[31] R. R. Brooks, "Biogeochemistry and hyperaccumulators," in Plants That Hyperaccumulate Heavy Metals, R. R. Brooks, Ed., CAB International, Wallingford, UK, 1998.

[32] Q. Kfayatullah, M. Tahir Shah, and M. Arfan, "Biogeochemical and environmental study of the chromite-rich ultramafic terrain of Malakand area, Pakistan," Environmental Geology, vol. 40, no. 11-12, pp. 1482-1486, 2001.

[33] R. D. Reeves and N. Adigüzel, "Rare plants and nickel accumulators from Turkish serpentine soils, with special reference to Centaurea species," Turkish Journal of Botany, vol. 28, no. 1-2, pp. 147-153, 2004.

[34] B. W. Wood, C. C. Reilly, and A. P. Nyczepir, "Mouse-ear of Pecan: a nickel deficiency," HortScience, vol. 39 , no. 6, pp. 1238 1242, 2004.

[35] J. L. Freeman, M. W. Persans, K. Nieman et al., "Increased glutathione biosynthesis plays a role in nickel tolerance in Thlaspi nickel hyperaccumulators W inside box sign," Plant Cell, vol. 16, no. 8, pp. 2176-2191, 2004.

[36] Z. Hassan and M. G. M. Aarts, "Opportunities and feasibilities for biotechnological improvement of $\mathrm{Zn}, \mathrm{Cd}$ or Ni tolerance and accumulation in plants," Environmental and Experimental Botany, vol. 72, no. 1, pp. 53-63, 2011.

[37] H. F. Li, C. Gray, C. Mico, F. Zhao, and S. P. McGrath, "Phytotoxicity and bioavailability of cobalt to plants in a range of soils," Chemosphere, vol. 75, no. 7, pp. 979-986, 2009.

[38] H. L. Bohn, B. L. McNeal, and G. A. O'Connor, Soil Chemistry, Wiley, New York, NY, USA, 3rd edition, 2001.

[39] A. Sagiroglu, A. Sasmaz, and Ö. Sen, "Hyperaccumulator plants of the Keban mining district and their possible impact on the environment," Polish Journal of Environmental Studies, vol. 15, no. 2, pp. 317-325, 2006.

[40] J. B. Jones, "Plant tissue analysis for micronutrients," in Micronutrients in Agriculture, J. J. Mortvedt, P. M. Giorando, and W. L. Lindsay, Eds., p. 319, Soil Science Society of America Journal, Madison, Wis, USA, 1972.

[41] Board of Agriculture, Nutrient Requirement of Beef Cattle Edition, Board of Agriculture, The National Academies Press, Washington, DC, USA, 7th edition, 1996.

[42] I. Mewis, H. M. Appel, A. Hom, R. Raina, and J. C. Schultz, "Major signaling pathways modulate Arabidopsis glucosinolate accumulation and response to both phloem-feeding and chewing insects," Plant Physiology, vol. 138, no. 2, pp. 1149-1162, 2005.

[43] D. S. Manta, M. Angelone, A. Bellanca, R. Neri, and M. Sprovieri, "Heavy metals in urban soils: a case study from the city of Palermo (Sicily), Italy," Science of the Total Environment, vol. 300, no. 1-3, pp. 229-243, 2002. 

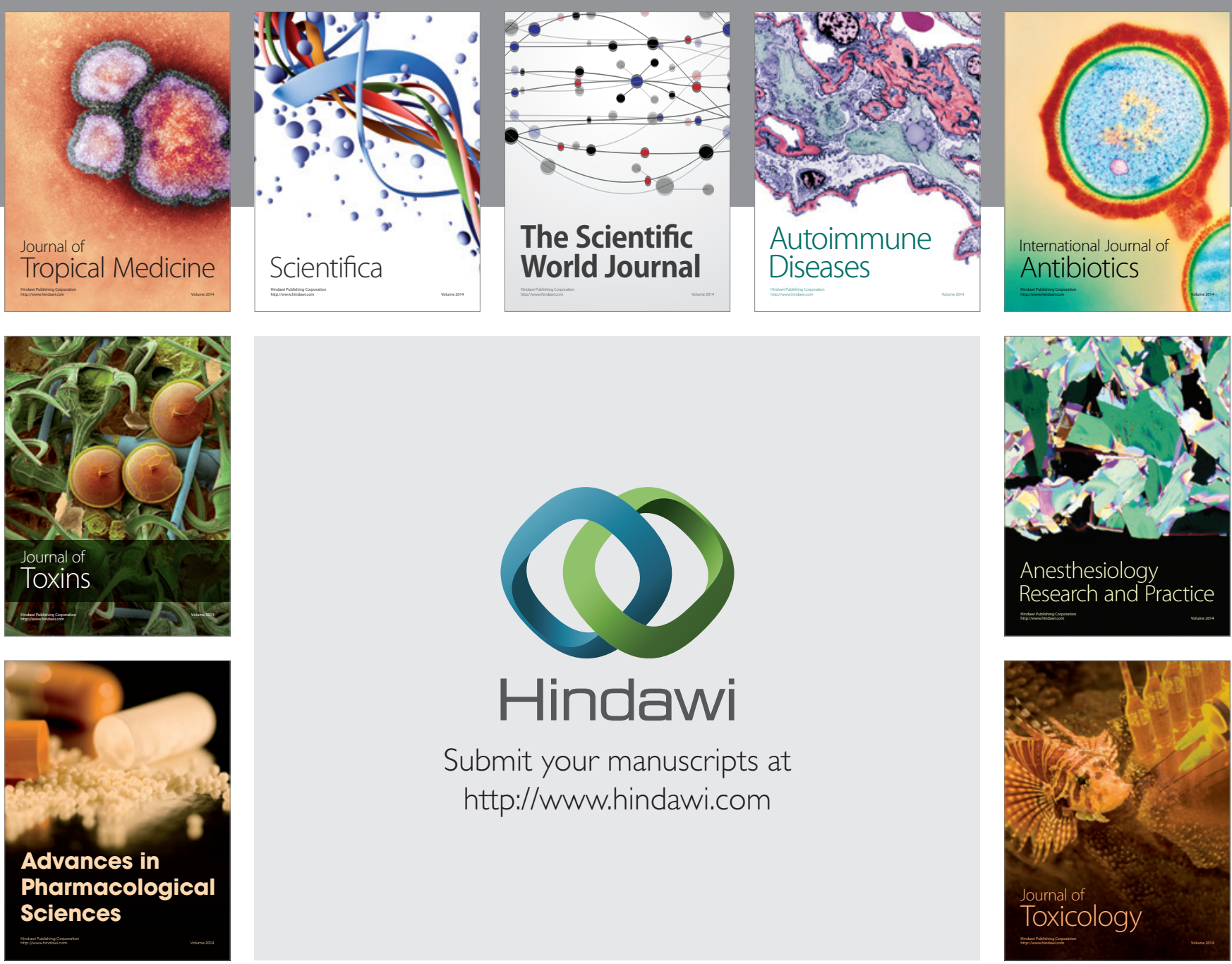

\section{Hindawi}

Submit your manuscripts at

http://www.hindawi.com
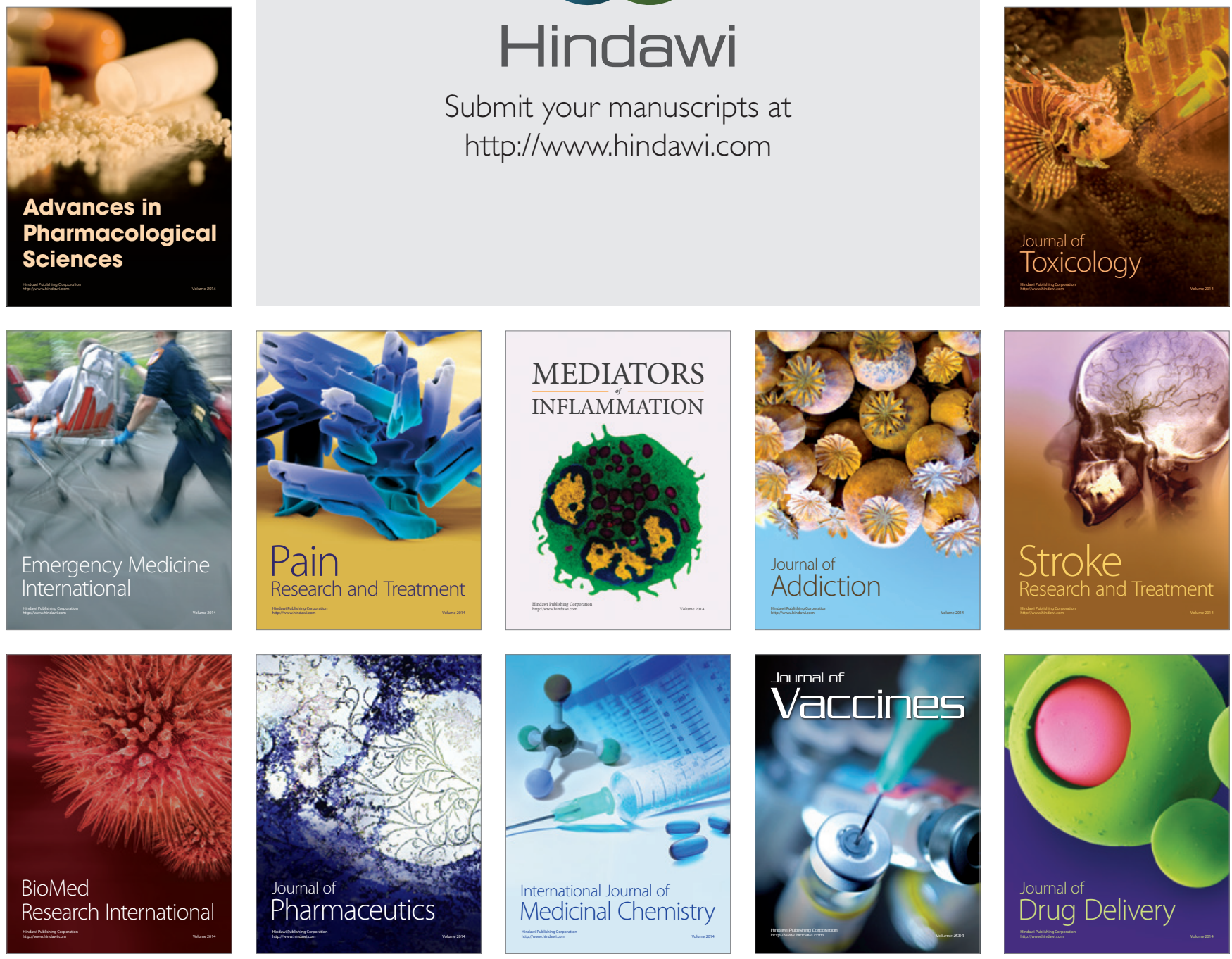